\title{
Global Innovational Networks: Sense and Role in Development of Global Economy
}

\author{
Egor V. Dudukalov', Natalia D. Rodionova², Yana E. Sivakova³ ${ }^{3}$ Elena Vyugova ${ }^{4}$, Irina V. Cheryomushkina ${ }^{5}$, \\ Elena G. Popkova ${ }^{6}$
}

ABSTRACT

The starting point for this research is the authors' hypothesis that global innovational networks play an important role in the development of the modern global economy because they stimulate international cooperation in the innovational sphere, the translation of knowledge in the global economic system, and general scientific and technological development and production development.

The purpose of this article is to verify this hypothesis, conduct a complex study on the phenomenon of global innovational networks, and determine their purpose and role in the development of the modern global economy. The methodological basis of this research is founded on the logical modeling of economic systems and methods of structural and functional, systemic, and problem analysis.

In the process of the research, the authors studied examples of global innovational networks created based on modern Europe that include countries from all over the world, namely, Horizon 2020, ERA.Net RUS, and Eurocores (European Collaboration Research). The authors also conducted complex analysis of statistical information on various global innovational networks, the dynamics of the quantity of innovational projects, realized participation in global innovational networks, and the significance of the global innovational indexes of countries of Western Europe (Great Britain, Germany, France, and Italy), Central and Eastern Europe (Czech Republic, Poland, Hungary, and Latvia) and Russia in 2005-2014.

The authors provide a sense of global innovational networks, including their peculiarities and advantages; build a structural and logical model of the global market of innovations; and determine the role of global innovational networks in the development of the modern global economy.

KEY WORDS: $\quad$ global innovational networks, globalization, global economy, economic development

JEL Classification: F630, 0190

${ }^{1}$ Russian Presidential Academy of National Economy and Public Administration, Russia; ${ }^{2}$ Rostov State Economic University (RINH), Russia; ${ }^{3}$ nnstitute of Management - Branch of Russian Presidential Academy of National Economy and Public Administration, Russia; ${ }^{4}$ Institute of Economics and Finance, Russia; ${ }^{5}$ Voronezh State University of Engineering Technologies, Russia; ${ }^{\circ}$ Volgograd State Technical University, Russia

\section{Introduction}

As the global economy develops, it acquires more and more new members. Under the influence of integra$\underline{\square}$ tion processes, modern businesses have taken various

Correspondence concerning this article should be addressed to: Elena G. Popkova, Volgograd State Technical University, 28 Lenina St., Volgograd, Russian Federation. E-mail: elenapopkova@yahoo.com forms. One of the most vivid manifestations is the emergence of transnational corporations in the $20^{\text {th }}$ century, which currently have strong positions in the global economic system. As the concept of innovational economic development in the global economy has expanded, new members - global innovational networks - have appeared. These networks were selected as the object of this research. 
Global innovational networks are a form of international cooperation among enterprises in the sphere of scientific research and development for the creation of innovational technologies and their implementation in production. They can be created in any sphere of economic activity. Their members could include entrepreneurial structures, R\&D institutes, and other subjects of economic activities of any ownership form. The organizational structure of global innovational networks differs depending on the specifics of the sphere and its subjects.

In the case of the registration of patents based on joint international developments within global innovational networks, network members possess equal rights to them. Overall, the activities of global innovational networks are regulated by international norms of law. It should be noted that recent initiators and members of global innovational networks have included representatives of developing countries. Joint projects, which are conducted with close cooperation within such networks, provide innovational development of the economies of all network members.

The authors of this research offer a scientific hypothesis that global innovational networks play an important role in the development of the modern global economy because they stimulate international cooperation in the sphere of innovation, the translation of knowledge in the global economic system, and general scientific, technical and production development. The purpose of the article is to verify this hypothesis, conduct a complex study of the phenomenon of global innovational networks, and determine their sense and role in the development of the modern global economy.

\section{Literature review}

The theoretical basis of the research comprises the works of various authors in the spheres of analyzing the consequences of the globalization of economic activities, the functioning of transnational corporations, and other international entrepreneurial structures; studying the tendencies of development of international business at modern stage; studying the issues of international production and sales cooperation; studying the transformation of national business environments and business societies and the formation of global business; and determining perspectives for the further expansion of international movement of production factors. Many researchers have publications on this topic (Bagwell, 2015; Lan, 2015, \& Thauer, 2015). The globalization of the world economy has led to transnational corporations, which conduct their business activities at the international scale (Eberlein, Abbott, Black, Meidinger, \& Wood, 2014). Transnational businesses strive to place their production in countries with the cheapest natural and human resources (Porter, 2014), through which the least developed countries receive investments and opportunities for development (Lee, Ryu, \& Kang, 2014).

This research is based on studies by modern authors in the spheres of studying the sense of the phenomenon of global innovational networks, their differences from other players in the international markets, the specifics of the organization of their activities and the cooperation of members in such networks and studying the issues of cooperation in global innovational networks with the governments of the countries in which they are represented and specific aspects of their activities, including taxation, crediting, and investments (Chaminade \& Plechero, 2015; Cooke, 2013; Herstad, Aslesen, \& Ebersberger, 2014; Liu, Chaminade, \& Asheim, 2013; Ribeiro et al., 2014; Schøtt, Cheraghi, Rezaei, \& Vang, 2014; Silva \& Klagge, 2013; van Egeraat \& Kogler, 2013).

Global innovational networks are global centers of innovational activities that accumulate new knowledge and stimulate their implementation in the production activities of business structures (Liu et al., 2013). They ensure innovational activity in the global economy; therefore, they often receive tax subsidies and credit resources (Silva \& Klagge, 2013). The governments of various countries strive to attract global innovational networks and create them based on their own economies (Cooke, 2013).

The article also uses the works of economists devoted to the analysis of tendencies and factors of development of the modern global economy and the determination of new vectors of its growth and the influence of globalization and integration on the development of the global economy. They study various aspects of globalization of specific markets and spheres of the economy, the functioning and development of integration associations, international cooperation in solving global economic problems of humankind, and 

Table 1. Dynamics of quantity of innovational projects realized within participation in global innovational networks and values of global innovational index of countries of Western, Central, and Eastern Europe and Russia in 2005-2009

\begin{tabular}{|c|c|c|c|c|c|c|c|c|c|c|}
\hline \multirow{3}{*}{ Countries } & \multicolumn{10}{|c|}{ Year/Indicators } \\
\hline & \multicolumn{2}{|c|}{2005} & \multicolumn{2}{|c|}{2006} & \multicolumn{2}{|c|}{2007} & \multicolumn{2}{|c|}{2008} & \multicolumn{2}{|c|}{2009} \\
\hline & Q & I & Q & । & Q & I & Q & । & Q & I \\
\hline \multicolumn{11}{|c|}{ Countries of Western Europe } \\
\hline Great Britain & 448 & 0.08 & 574 & 0.10 & 396 & 0.07 & 885 & 0.16 & 1,008 & 0.18 \\
\hline Germany & 427 & 0.18 & 423 & 0.18 & 266 & 0.11 & 715 & 0.30 & 616 & 0.26 \\
\hline France & 389 & 0.25 & 357 & 0.23 & 256 & 0.16 & 407 & 0.26 & 530 & 0.34 \\
\hline Italy & 419 & 0.38 & 291 & 0.26 & 228 & 0.20 & 395 & 0.35 & 448 & 0.40 \\
\hline \multicolumn{11}{|c|}{ Countries of Central and Eastern Europe } \\
\hline Czech Republic & 75 & 0.09 & 80 & 0.11 & 85 & 0.08 & 91 & 0.17 & 97 & 0.20 \\
\hline Poland & 55 & 0.05 & 60 & 0.05 & 65 & 0.03 & 71 & 0.09 & 78 & 0.08 \\
\hline Hungary & 34 & 0.38 & 37 & 0.34 & 40 & 0.25 & 44 & 0.39 & 48 & 0.51 \\
\hline Latvia & 28 & 0.32 & 32 & 0.22 & 37 & 0.18 & 42 & 0.30 & 48 & 0.34 \\
\hline \multicolumn{11}{|c|}{ Russia } \\
\hline Russia & 3 & 0.02 & 5 & 0.03 & 6 & 0.04 & 10 & 0.06 & 17 & 0.10 \\
\hline
\end{tabular}

Source: Adapted from “The Global Innovation Index 2015: Effective Innovation Policies for Development” by Dutta, Bernard, Reynoso, Lanvin and Wunsch-Vincent (2015).

Note:

$\mathrm{Q}$ - quantity of innovational projects realized within participation in global innovational networks;

I - value of global innovational index.

Another interesting global innovational network is Eurocores (European Collaboration Research), which includes 68 innovational enterprises from 24 countries of Europe. Within Eurocores, multiple scientific and research conferences are held, and many innovational projects are realized, the total budget of which constitutes more than EUR 50 billion (European Science Foundation, 2009).

These examples of global innovational networks were created around large European investment funds that conduct wide circles of research, concentrated around the most perspective spheres of science - nanotechnologies, breakthrough medicine technologies, etc. - and, despite their global coverage, have many members from the regions in which they were created.

The sense of global innovational networks consists of the unification of efforts of innovational enterprises and $R \& D$ centers from various countries for the joint conduct of scientific research and creation of innovations. The most important peculiarities that determine the specifics and nature of the activities of global innovational networks are the following:

- the activities of global innovational networks have an innovational character - their acceptance of enterprises and R\&D centers from several countries of the world;

- global innovational networks feature the realization of large projects that are characterized by a high complexity and require special infrastructure and large investments;

- projects realized within such networks usually have large social significance, have a revolutionary direction in science and are held in top-priority spheres of activities;

- global innovational networks are created for a certain period of time, have a clear goal, and cease to exist (or are re-organized) after its achievement;

- the initiator of network creation is, as a rule, a large investment fund that is interested in conducting scientific research. 
Table 2. Dynamics of quantity of innovational projects realized within participation in global innovational networks and values of global innovational index of countries of Western, Central, and Eastern Europe and Russia in 2010-2014

\begin{tabular}{|c|c|c|c|c|c|c|c|c|c|c|}
\hline \multirow{3}{*}{ Countries } & \multicolumn{10}{|c|}{ Year/Indicators } \\
\hline & \multicolumn{2}{|c|}{2010} & \multicolumn{2}{|c|}{2011} & \multicolumn{2}{|c|}{2012} & \multicolumn{2}{|c|}{2013} & \multicolumn{2}{|c|}{2014} \\
\hline & Q & 1 & Q & I & Q & 1 & Q & 1 & Q & I \\
\hline \multicolumn{11}{|c|}{ Countries of Western Europe } \\
\hline Great Britain & 1,347 & 0.24 & 1,800 & 0.32 & 2,405 & 0.43 & 3,214 & 0.58 & 4,294 & 0.99 \\
\hline Germany & 796 & 0.33 & 1,029 & 0.43 & 1,329 & 0.56 & 1,718 & 0.72 & 2,220 & 0.92 \\
\hline France & 600 & 0.39 & 679 & 0.44 & 768 & 0.49 & 869 & 0.56 & 984 & 0.85 \\
\hline Italy & 487 & 0.44 & 529 & 0.47 & 574 & 0.52 & 624 & 0.56 & 677 & 0.79 \\
\hline \multicolumn{11}{|c|}{ Countries of Central and Eastern Europe } \\
\hline Czech Republic & 104 & 0.26 & 110 & 0.35 & 118 & 0.47 & 126 & 0.63 & 134 & 0.82 \\
\hline Poland & 85 & 0.10 & 93 & 0.13 & 101 & 0.17 & 110 & 0.22 & 120 & 0.69 \\
\hline Hungary & 52 & 0.58 & 56 & 0.66 & 61 & 0.74 & 67 & 0.84 & 73 & 0.76 \\
\hline Latvia & 55 & 0.37 & 62 & 0.41 & 71 & 0.44 & 81 & 0.48 & 93 & 0.77 \\
\hline \multicolumn{11}{|c|}{ Russia } \\
\hline Russia & 25 & 0.15 & 31 & 0.18 & 39 & 0.23 & 46 & 0.27 & 53 & 0.66 \\
\hline
\end{tabular}

Source: Adapted from "The Global Innovation Index 2015: Effective Innovation Policies for Development" by Dutta, Bernard, Reynoso, Lanvin and Wunsch-Vincent (2015).

Note:

$\mathrm{Q}$ - quantity of innovational projects realized within participation in global innovational networks;

I - value of global innovational index.

Due to these peculiarities, global innovational networks have the following advantages:

- the attraction of investments for the realization of complex, high-risk, and long-term innovational projects, which, as a rule, is difficult during the performance of such projects on a national scale;

- the possibility of the creation of unique and costly infrastructure, necessary for the conduct of fullscale R\&D projects;

- the unification of resources and leading specialists from several countries, due to which the volume of innovational capital exceeds the possibilities of other members of the global market of innovations by several times.

Based on statistical information of for global innovational networks, the authors of this research determined (Table 1-2) and graphically presented (Fig. 1-6) dynamics of the quantity of innovational projects realized within participation in global innovational networks and the values of the global innovational index of countries of Western Europe (Great Britain, Germany, France, and Italy), Central and Eastern Europe (Czech Republic, Poland, Hungary, and Latvia), and Russia in 2005-2014.

The analysis of dynamics of the above indicators made it possible to determine the tendency of expansion of countries' cooperation in the creation of global innovational networks, which leads to an increase in the value of their global innovational index. The number of innovational projects realized through participation in global innovational networks selected for the study of countries of Western Europe increased 10 times over the past 10 years. The annual increase was $10-15 \%$. The value of the global innovational index increased proportionally from $0.08-0.25$ to $0.85-0.99$.

The quantity of innovational projects realized through participation in global innovational networks selected for the study of countries of Central and Eastern Europe increased 2 times over the past 10 years. 


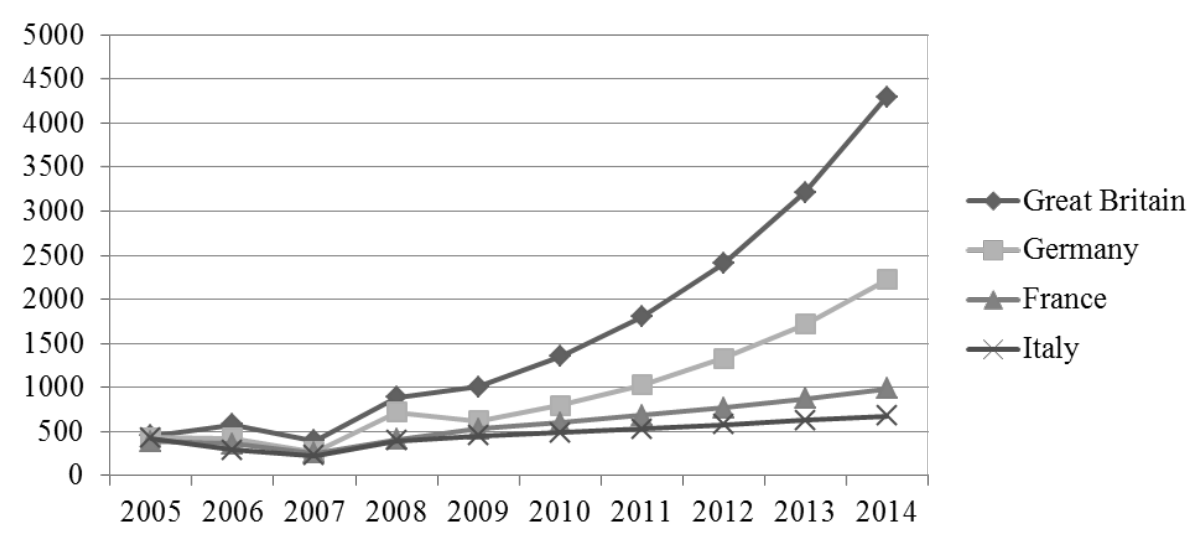

Figure 1. Number of innovational projects of countries of Western Europe realized within participation in global innovational networks in 2005-2014

Adapted from "The Global Innovation Index 2015: Effective Innovation Policies for Development" by Dutta, Bernard, Reynoso, Lanvin and Wunsch-Vincent (2015). ; "Funded innovation projects" by ERA.Net RUS Plus (2015); "EUROCORES Scheme European Collaborative Research. Final Activity Report" by European Science Foundation (2009).

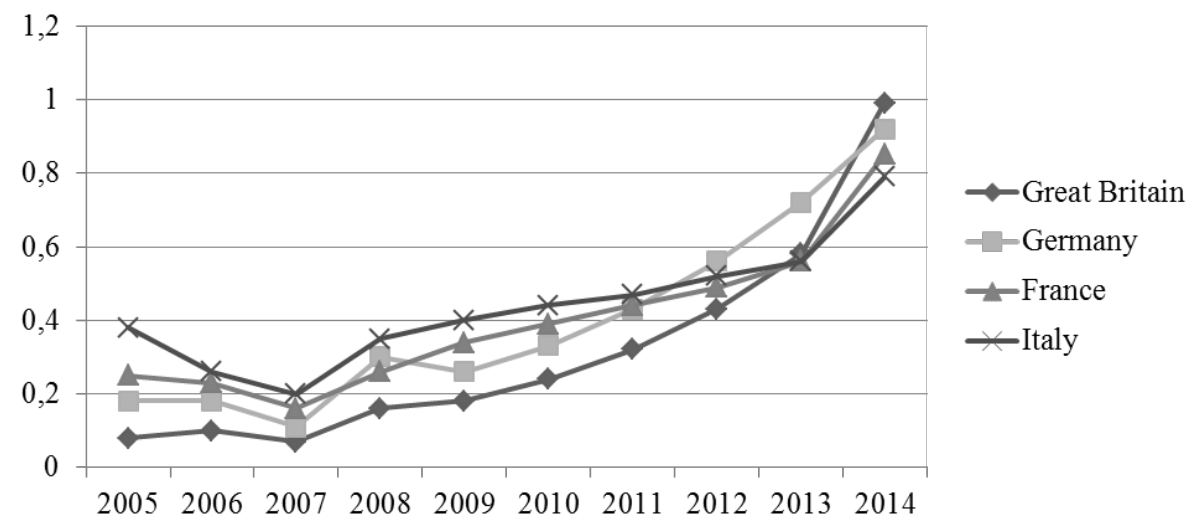

Figure 2. Global innovational index of countries of Western Europe in 2005-2014 Adapted from "The Global Innovation Index 2015: Effective Innovation Policies for Development" by Dutta, Bernard, Reynoso, Lanvin and Wunsch-Vincent (2015). ; "Funded innovation projects" by ERA.Net RUS Plus (2015); "EUROCORES Scheme European Collaborative Research. Final Activity Report" by European Science Foundation (2009). 


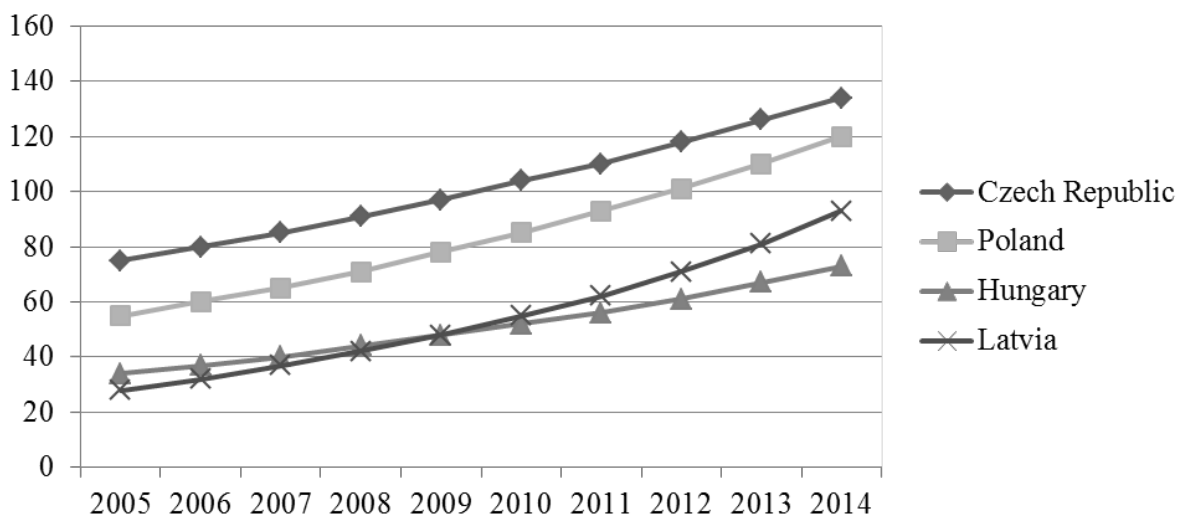

Figure 3. Number of innovational projects of countries of Central and Eastern Europe realized within participation in global innovational networks in 2005-2014

Adapted from "The Global Innovation Index 2015: Effective Innovation Policies for Development" by Dutta, Bernard, Reynoso, Lanvin and Wunsch-Vincent (2015).; ; "Funded innovation projects" by ERA.Net RUS Plus (2015); “EUROCORES Scheme European Collaborative Research. Final Activity Report" by European Science Foundation (2009).

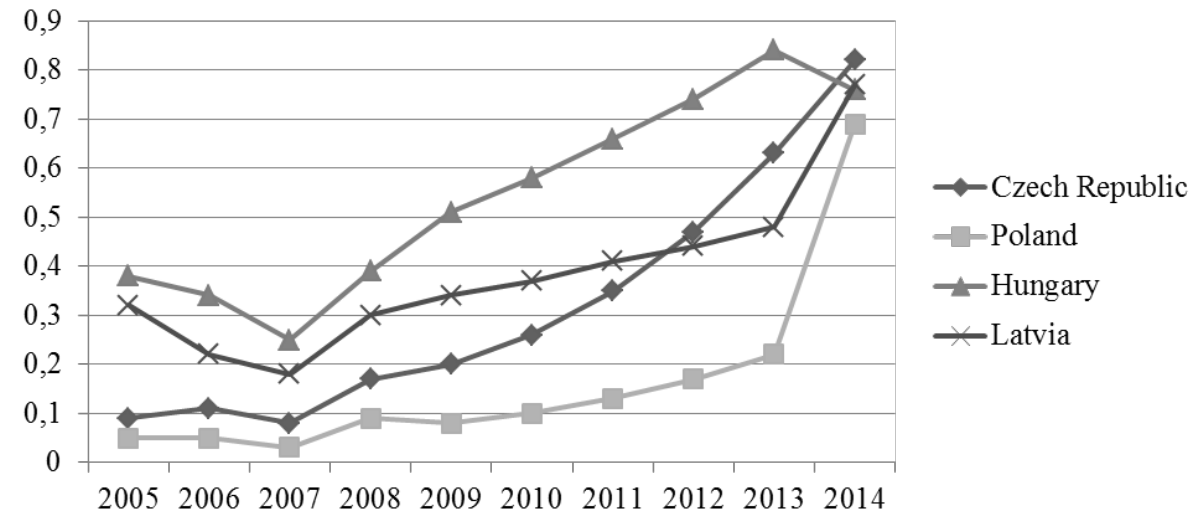

Figure 4. Global innovational index of countries of Central and Eastern Europe in 2005-2014

Adapted from "The Global Innovation Index 2015: Effective Innovation Policies for Development" by Dutta, Bernard, Reynoso, Lanvin and Wunsch-Vincent (2015).; ; "Funded innovation projects" by ERA.Net RUS Plus (2015); “EUROCORES Scheme European Collaborative Research. Final Activity Report" by European Science Foundation (2009). 


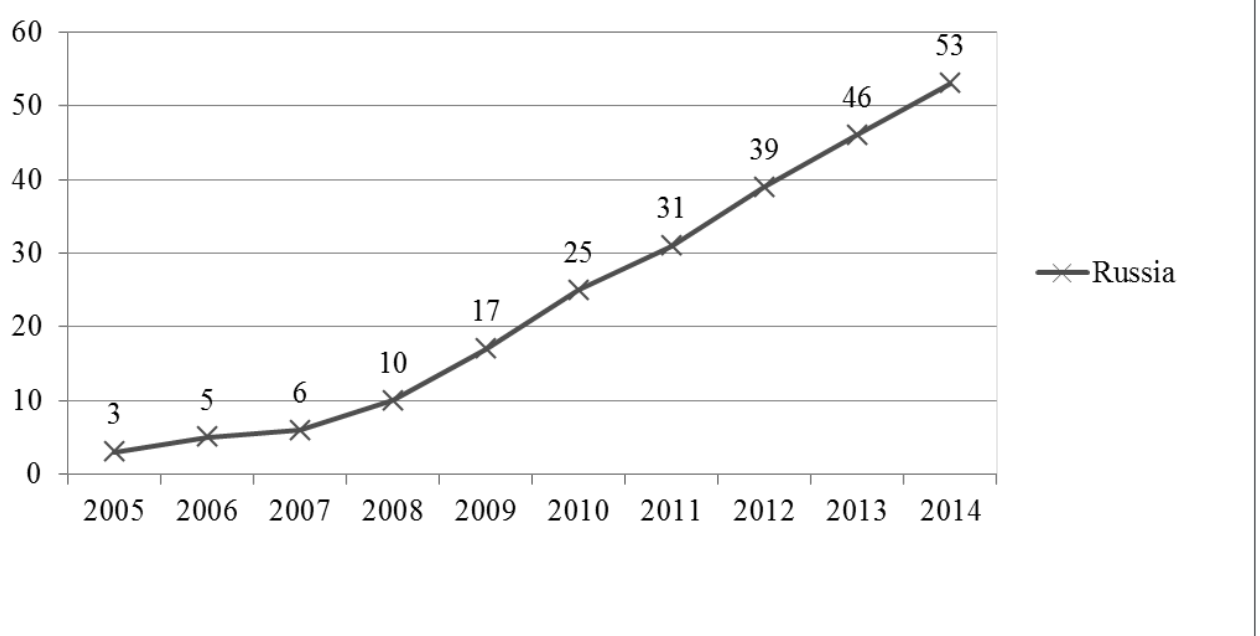

Figure 5. Number of innovational projects of Russia realized within participation in global innovational networks in 2005-2014 Adapted from "The Global Innovation Index 2015: Effective Innovation Policies for Development" by Dutta, Bernard, Reynoso, Lanvin and Wunsch-Vincent (2015). ; "Funded innovation projects" by ERA.Net RUS Plus (2015); "EUROCORES Scheme European Collaborative Research. Final Activity Report" by European Science Foundation (2009).

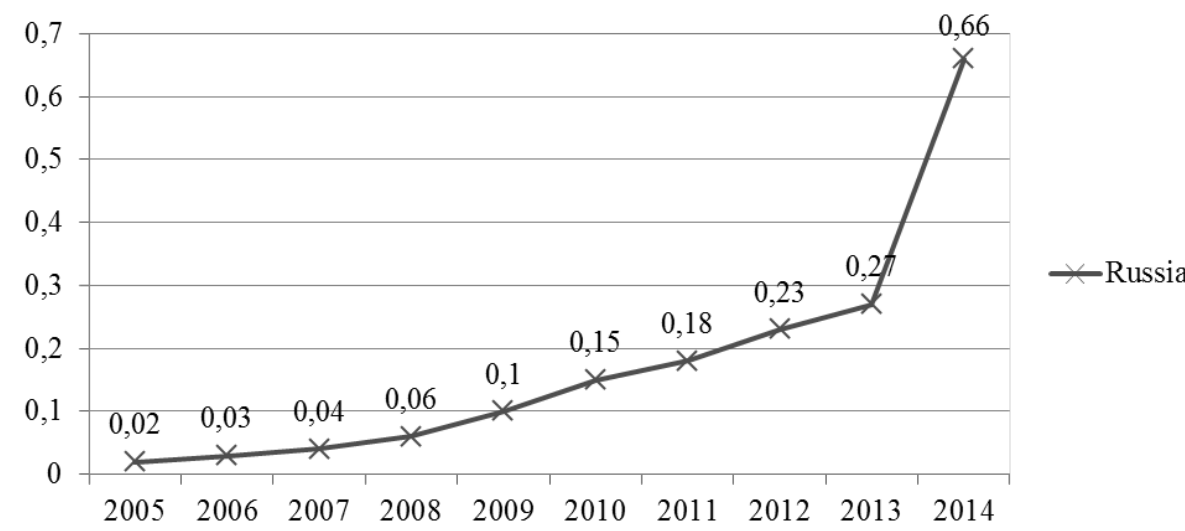

Figure 6. Global innovational index of Russia in 2005-2014

Adapted from "The Global Innovation Index 2015: Effective Innovation Policies for Development" by Dutta, Bernard, Reynoso, Lanvin and Wunsch-Vincent (2015). ; "Funded innovation projects" by ERA.Net RUS Plus (2015); "EUROCORES Scheme European Collaborative Research. Final Activity Report" by European Science Foundation (2009). 


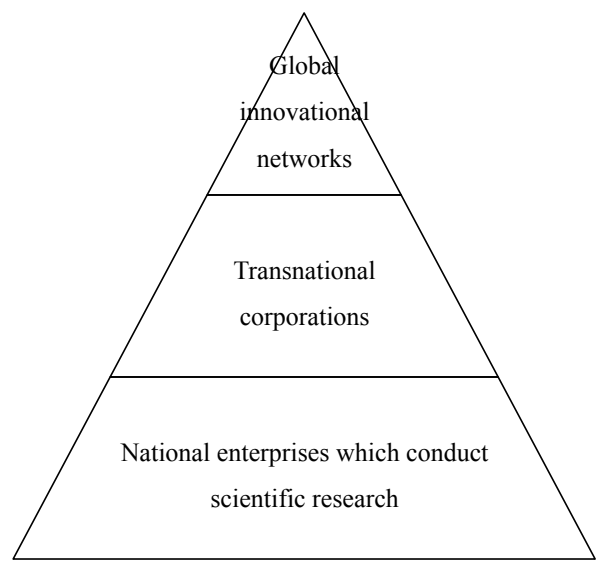

Goal: development of science;

Scale: global;

Character of research:

revolutionary;

Goal: supporting competitiveness;

Scale: regional;

Character of research:

evolutionary;

Goal: supporting competitiveness;

Scale: national;

Character of research: evolutionary;

Figure 7. Structural and logical model of global market of innovations

The annual increase was $6-8 \%$. The value of the global innovational index increased proportionally from 0.05-0.09 to $0.75-0.85$.

The largest growth in the quantity of innovational projects realized through participation in global innovational networks was found for Russia. Over the past 10 years, it grew 17 times. The annual growth was $25-30 \%$. The value of the global innovational index increased proportionally from 0.02 to 0.66 . To determine the position and role of global innovational networks in the development of the modern global economy, let us view the proprietary logical model of the global market of innovations (Fig. 7).

As seen from Fig. 7, the global market of innovations is founded on national enterprises that conduct scientific research. They create most of the innovations. This is necessary for supporting their competitiveness in domestic markets. Their research is focused on a national scale, has an evolutionary character, and aims at slight improvements in manufactured products. Their budget is no more than several thousands of dollars.

Transnational corporations are also in the center of the global market of innovations. They conduct scien- tific research to support their competitiveness, but in the international markets. Their research has regional coverage and is focused on the regions in which their main centers are located. Their research has an evolutionary character and aims at the significant improvement of manufactured products. The budget of their research may reach several millions of dollars.

On the top of the global market of innovations, there are global innovational networks. They do not seek to support the competitiveness of their members but rather strive for breakthroughs in modern science. They conduct research at the global scale. The character of their research is revolutionary because they are aimed not at the perfection of usual products but at the creation of completely new technologies and development of completely new products. The budget of global innovational networks can be billions of dollars.

Because of the structural and functional analysis of the compiled logical model, it is possible to conclude that global innovational networks are drivers of innovational development in the global economy. Being a locomotive of modern scientific research, they create a scientific and technological base for 
the research and development of innovational products by transnational corporations and national innovational enterprises.

\section{Conclusion}

The offered hypothesis was proven, and the authors concluded that global innovational networks play an important role in the development of the modern global economy. With vast scientific research, they create a technical and methodological basis for the research and development of innovational products by transnational corporations and national innovational enterprises.

The complex study of the phenomenon of global innovational networks made it possible to determine that they consisted of the unification of efforts of innovational enterprises and R\&D centers from various countries for joint conduct of scientific research and creation of innovations.

The most important peculiarities that determine the specifics and characteristics of the activities of global innovational networks are the international character of activities, the realization of large projects, the revolutionary direction of $\mathrm{R} \& \mathrm{D}$, clear goal setting, and initiation by large investment funds. The advantages of global innovational networks are the attraction of significant investments, the creation of unique infrastructure, and a large volume of innovational capital.

It should be concluded that although the fact that the share of the global market of innovations constitutes 3-5\% of the global GDP in quantitative terms, in qualitative terms, this market stimulates the development of the global economic system because it provides fuller satisfaction of global public needs, stimulates the effectiveness of the use of existing resources, and increases the sustainability of the development of the global economy.

The limitations of the conducted research include the limited selection of countries and global innovational networks, due to which, not all the peculiarities and advantages of their activities could be determined. As a direction of further research in this sphere, global innovational networks based around Asian, African, American, and Australian investors could be studied to determine common regularities of their development.

\section{References}

Bagwell, S. (2015). Transnational entrepreneurship amongst Vietnamese businesses in London. Journal of Ethnic and Migration Studies, 41(2), 329-349.

Castiglione, C., Infante, D., Smirnova, J. (2015). Environment and economic growth: is the rule of law the go-between? The case of high-income countries. Energy, Sustainability and Society, 5(26). doi:10.1186/s13705-015-0054-8.

Čaušević, F. (2015). Globalization. Southeastern Europe, and the World Economy. London, UK: Routledge.

Chaminade, C., Plechero, M. (2015). Do regions make a difference? Regional innovation systems and global Iinnovation networks in the ICT Industry. European Planning Studies, 23(2), 215-237.

Choi, K. H., Shin, S. (2015). Population aging, economic growth, and the social transmission of human capital: An analysis with an overlapping generations model. Economic Modelling, 50, 138-147.

Cooke, P. (2013). Qualitative analysis and comparison of firm and system incumbents in the new ICT global innovation network. European Planning Studies, 21(9), 1323-1340.

Docquier, F., Machado, J. (2015). Global Competition for Attracting Talents and the World Economy. The World Economy, 39(4), 530-542.

Dudin, M. N., Frolova, E. E. (2015). The balanced scorecard as a basis for strategic company management in the context of the world economy transformation. Asian Social Science, 11(3), 282-288.

Dutta, S., Bernard, A. L., Reynoso, E. R., Lanvin, B., \& Wunsch-Vincent, S. (2015). The Global Innovation Index 2015: Effective Innovation Policies for Development. In S. Dutta, B. Lanvin, \& S. Wunsch-Vincent (Eds.), The Global Innovation Index 2015. Effective Innovation Policies for Development (pp. 3-39). Ithaca, NY: Cornell University. Retrieved from https://www.globalinnovationindex.org/userfiles/file/reportpdf/GII-2015-v5.pdf

Eberlein, B., Abbott, K. W., Black, J., Meidinger, E., Wood, S. (2014). Transnational business governance interactions: Conceptualization and framework for analysis. Regulation and Governance, 8(1), 1-21.

ERA.Net RUS Plus (2015). Funded innovation projects. Retrieved from http://www.eranet-rus. eu/_media/ERANet_RUS_Plus_Funded_Innovation_projects.pdf 
European Science Foundation (2009). EUROCORES Scheme European Collaborative Research. Final Activity Report. Retrieved from http://www.esf. org/index.php?eID =tx_nawsecuredl $\& u=0 \& g=0$ $\& \mathrm{t}=1446044498 \&$ hash $=\mathrm{dc} 9073 \mathrm{a} 6 \mathrm{c} 14 \mathrm{ce} 8 \mathrm{bc53e} 5 \mathrm{f}$ 3258a62d570d48430de\&file=fileadmin/be_user/ activities/EUROCORES/EUROCORES_Scheme/ EUROCORES_Scheme_documents/EUROCORES\%20Final\%20Report-\%20\%28modified\%2020-nov-09\%29.pdf

European Commission. (2015). Horizon 2020. The EU Framework Programme for Research and Innovation. Retrieved from http://ec.europa.eu/programmes/horizon 2020

González-Pernía, J. L., Peña-Legazkue, I. (2015). Export-oriented entrepreneurship and regional economic growth. Small Business Economics, 45(3), 505-522.

Herstad, S. J., Aslesen, H. W., Ebersberger, B. (2014). On industrial knowledge bases, commercial opportunities and global innovation network linkages. Research Policy, 43(3), 495-504.

Ilie, C., Jaradat, M. (2015). Co-operation in the world economy. Quality - Access to Success, 16, 168-173.

Klinov, V. G. (2015). The evolution of long waves in the world economy. Studies on Russian Economic Development, 26(3), 285-294.

Kornev, A. K., Maksimtsova, S. I., Treshchina, S. V. (2015). Experience in world industrial development and the reindustrialization of the domestic economy. Studies on Russian Economic Development, 26(5), 460-469.

Lan, S. (2015). Transnational business and family strategies among Chinese/Nigerian couples in Guangzhou and Lagos. Asian Anthropology, 14(2), 133-149.

Larionova A. A., Suslova I. A., Povorina E.V., Vinogradova M. V. (2015). Formation of tourist image of the region. Mediterranean Journal of Social Sciences, 6(3), 261-266.

Lee, J. Y., Ryu, S., Kang, J. (2014). Transnational HR network learning in Korean business groups and the performance of their subsidiaries. International Journal of Human Resource Management, 25(4), 588-608.

Lee, S., Oh, D. W. (2015). Economic growth and the environment in China: Empirical evidence using prefecture level data. China Economic Review, 36, 870, 73-85.
Leonida, L., Maimone Ansaldo Patti, D., Marini, A., Navarra, P. (2015). Political competition and economic growth: A test of two tales. Economics Letters, 135, 96-99.

Liu, J., Chaminade, C., Asheim, B. (2013). The geography and structure of global innovation networks: A knowledge base perspective. European Planning Studies, 21(9), 1456-1473.

Odhiambo, N. M. (2015). Government expenditure and economic growth in South Africa: An empirical investigation. Atlantic Economic Journal, 43(3), 393-406.

Pogosov, I. A. (2015). Factors of long-term economic growth: Scientific and technical progress and capital intensity of production. Studies on Russian Economic Development, 26(5), 423-433.

Popkova, E. G., Yurev, V., Stepicheva, O., Denisov, N. (2015). Transformation and concentration of intellectual capital as a factor of economic growth in the modern economy. Regional and Sectoral Economic Studies, 15(1), 53-60.

Porter, T. (2014). Technical systems and the architecture of transnational business governance interactions. Regulation and Governance, 8(1), 110-125.

Pulselli, F. M., Coscieme, L., Neri, L., Regoli, A., Sutton, P. C., (...), Bastianoni, S. (2015). The world economy in a cube: A more rational structural representation of sustainability. Global Environmental Change, 35, 41-51.

Ribeiro, L. C., Kruss, G., Britto, G., Bernardes, A. T., da Motta e Albuquerque, E. (2014). A methodology for unveiling global innovation networks: patent citations as clues to cross border knowledge flows. Scientometrics, 101(1), 61-83.

Sarracino, F., Bartolini, S. (2015). The dark side of Chinese growth: Declining social capital and wellbeing in times of economic boom. World Development, 74, 333-351.

Schøtt, T., Cheraghi, M., Rezaei, S., \& Vang, J. (2014). Innovation embedded in entrepreneurs' networks in private and public spheres: A global study focusing on China and Denmark. International Journal of Entrepreneurship and Small Business, 23(1-2), 145-167.

Silva, P. C., Klagge, B. (2013). The evolution of the wind industry and the rise of Chinese firms: From industrial policies to global innovation networks. European Planning Studies, 21(9), 1341-1356. 
Thauer, C. R. (2015). In need of meta-governance: Business networks of transnational governance. Israel Law Review, 48(2), 189-218.

Van Egeraat, C., Kogler, D. F. (2013). Global and regional dynamics in knowledge flows and innovation networks. European Planning Studies, 21(9), 1317-1322.

Vinogradova, M. V., Kulyamina, O. S., Koroleva V. A., Larionova A. A. (2015). The Impact of Migration Processes on the National Security System of Russia. Mediterranean Journal of Social Sciences, 6(3), 161-168.

Wirtz, J., Tuzovic, S., \& Ehret, M. (2015). Global business services: Increasing specialization and integration of the world economy as drivers of economic growth. Journal of Service Management, 26(4), 565-587.

Yakovleva, E. A., Azarova, N. A., Titova, E. V. (2015). Innovation as a vector of regional economic development and a necessary condition for the progress of the world economy. Asian Social Science, 11(20), 90-96.

Zeira, J., Zoabi, H. (2015). Economic growth and sector dynamics. European Economic Review, 79, 1-15.

\section{Acknowledgements}

This work was performed within the Federal Target Program "Researches and development in the priority directions of development of a scientific and technological complex of Russia for 2014-2020" according to the agreement №14.577.21.0139 about subsidization (the unique identifier of scientific researches and experimental development RFMEFI57714X0139).

This work was performed with financial support of the Ministry of Education and Science of the Russian Federation. Project No. 2797 "Formation of the system of scientific and production clusters in Russian regions".

This work was performed with financial support of the Russian Humanitarian Scientific Fund. Project No. 15-

22-01011 "Theoretical and methodological foundations of marketing provision of innovational development of intellectual resources of the Republic of Belarus and the Russian Federation under the conditions of economic integration (by the example of creation of universities of entrepreneurial type)" 